Sains Malaysiana 49(8)(2020): 1925-1934

http://dx.doi.org/10.17576/jsm-2020-4908-14

\title{
Effect of Polyacrylamide on Compression Rate of Lime Stabilized Soil
}

(Kesan Poliakrilamida terhadap Kadar Pemampatan Tanah Terstabil Kapur)

\author{
MingXing GaO*, Feilong Yuan, Yanhua Xue \& Peng Guan
}

\begin{abstract}
In order to explore the influence mechanism of polyacrylamide on the compressibility of lime-stabilized soil, polyacrylamide with different contents was added to lime-stabilized soil, and the relationship between the consolidation coefficient and the consolidation pressure was obtained through one-dimensional laboratory consolidation experiment, and samples were taken for nitrogen adsorption experiment and observation with solid microscope. The results show that the microscopic image shows that the reaction of polyacrylamide with lime will form a spatial network structure; $0.24 \%$ polyacrylamide can effectively reduce the compression of lime stabilized soil, and the porosity ratio of solidified soil can be increased by $15.4 \%$, and the consolidation rate can be accelerated by $413.2 \%$. The pore volume distribution shows that the addition of polyacrylamide to lime stabilized soil can reduce the mesopore volume of the solidified soil and produce ultra-large pores. At the same time, the porosity ratio of the solidified soil is increased, which is beneficial to the drainage of super-pore water in the soil, accelerate the consolidation rate of solidified soil, shortens the time of consolidation and stability of the soil.
\end{abstract}

Keywords: Consolidation coefficient; microscopic image; nitrogen adsorption; pore structure

ABSTRAK

Dalam usaha untuk mengkaji mekanisme kesan poliakrilamida terhadap kebolehmampatan tanah terstabil kapur, poliakrilamida berbeza kandungan ditambahkan kepada tanah terstabil kapur dan hubungan antara pekali penggabungan dan penyatuan tekanan diperoleh melalui uji kaji penyatuan satu dimensi dan sampel diambil untuk uji kaji penjerapan nitrogen dan pemerhatian dengan mikroskop pejal. Hasilnya, imej mikroskopik menunjukkan bahawa tindak balas poliakrilamida dengan kapur akan membentuk struktur rangkaian reruang; $0.24 \%$ poliakrilamida dapat mengurangkan pemampatan tanah terstabil kapur dengan berkesan dan keliangan tanah yang dipadatkan dapat ditingkatkan sebanyak $15.4 \%$ dan kadar penyatuan dapat dipercepat sebanyak $413.2 \%$. Taburan isi padu liang menunjukkan bahawa penambahan poliakrilamida kepada tanah yang terstabil kapur dapat mengurangkan isi padu tanah pejal, menghasilkan liang yang sangat besar dan meningkatkan nisbah keliangan tanah yang dipadatkan. Kadar penyatuan tanah yang dipadatkan memendekkan masa penyatuan dan kestabilan tanah.

Kata kunci: Imej mikroskopik; pekali penyatuan; penjerapan nitrogen; struktur liang

\section{INTRODUCTION}

In engineering construction, the differential settlement of subgrade soil has always been a major problem for road builders. Lime is usually added to the subgrade backfill material to enhance the filling strength and reduce the amount of material settlement to achieve the purpose of stabilizing the subgrade structure ( $\mathrm{Li}$ et al. 2016; Ojuri et al. 2017; Sharma et al. 2018). Compared with other materials, lime stabilized soil is used as a building material due to its advantages of in-situ material acquisition, low price and high strength.

The main feature of lime soil is that the strength increases with age, but the shortcoming is that the early strength is relatively low, and the consolidation rate of lime soil is slow, therefore, the lime soil subgrade is still settling continuously after the completion of construction.
This problem seriously affects the performance of lime stabilized soil (Jha \& Sivapullaiah 2017; Mashifana et al. 2018; Naeini et al. 2012; Nilo et al. 2019) and many scholars have conducted lots of research on this. Keramatikerman et al. (2016) studied the effect of slag on the strength and mechanical properties of lime stabilized soil. James et al. (2018) studied the effect of adding sugarcane ash (BA) on the strength of lime-stable expansive soil. Through analysis of the microstructure of stabilized soil composite materials, a dense matrix was obtained. Gadouri et al. (2017) found that adding sulfate to lime can significantly increase the strength of solidified soil. These research mainly focuses on the strength of lime, but ignores the problem of the slow consolidation rate of lime soil, and the consolidation rate of lime soil has a close relationship with its settlement. 
With the development of economy, road construction materials are constantly improving. The polymer organic soil curing agent is favoured by the engineering community because of its wide application, convenient construction, low cost, short construction period, and beneficial to ecological protection (Keykha et al. 2019; Mohammadi et al. 2015; Wang et al. 2018) and polyacrylamide (hereinafter referred to as PAM) is a representative polymer curing agent, which can effectively improve the performance of soil (Lentz 2015; Soltani-Jigheh et al. 2019). Barvenik et al. (1994) pointed out that PAM is an excellent soil conditioner, can improve the permeability of soil, water holding capacity, and soil structure stability. Mamedov et al. (2010) research shows that adding PAM to the soil can stabilize the soil particles and improve the cohesion and internal friction angle between the soil particles. Georgees et al. (2018) studied the mixing of cement and PAM into the soil, and analyzed the strength of the solidified soil by triaxial test. The results show that PAM can effectively improve the strength performance and elastic modulus of the soil compared with traditional soil-cement (Georgees et al. 2018). At present, scholars mainly focus on the evaluation of macroscopic characteristics such as the permeability, stability, strength, and viscoelasticity of polyacrylamide to the soil. However, the deformation and destruction of materials originate from the micro-scale and atomic scale of the material, that is, the characteristics of the material depend on the atomic structure and micro-structure of the material, the analysis of the microstructure of the material is the basis for recognizing the content of the material with certain characteristics and improving the material synthesis process (Fan 2008). Therefore, this study uses macro-micro scale research methods to deeply analyse the effect of polyacrylamide on the consolidation rate of lime stabilized soil, explore the pore structure characteristics of polyacrylamide-lime stabilized soil, and show the modification mechanism of polyacrylamide on lime stabilized soil from multiple angles.

\section{MATERIALS AND METHODS}

\section{EXPERIMENTAL DETAILS}

The soil used for the experiment was taken from the southern suburb of Hohhot, Inner Mongolia. The soil sample was selected as a common road construction material in the area. The soil sample had a low gradation, low plasticity index, and a large settlement in the later stage of construction. According to JTG E40-2007 'Road Geotechnical Test Regulations', the basic physical indexes of the soil samples are shown in Table 1.

TABLE 1. Basic physical index of soil sample

\begin{tabular}{ccccccc}
\hline Character & $\begin{array}{c}\text { Maximum dry } \\
\text { density } \\
\left(\mathrm{g} \cdot \mathrm{cm}^{-3}\right)\end{array}$ & $\begin{array}{c}\text { Optimum moisture } \\
\text { content }(\%)\end{array}$ & $\begin{array}{c}\text { Liquid limit } \\
(\%)\end{array}$ & $\begin{array}{c}\text { Plastic } \\
\text { limit }(\%)\end{array}$ & Plasticity index & Type \\
\hline Parameter & 2.006 & 11.2 & 26.40 & 15.52 & 10.88 & Fine grained gravel \\
\hline
\end{tabular}

This study uses locally produced fine quicklime powder with a fineness of up to 300 mesh, a molecular weight of 56.08 , a bulk density of 3.25 to $3.38 \mathrm{~kg} / \mathrm{m}^{3}$, and a melting point of 2580 to $2850{ }^{\circ} \mathrm{C}$, it is an inorganic alkaline etching article with a white appearance. Polyacrylamide adopts soluble anionic polyacrylamide produced by Duty City Xinbang Environmental Protection Technology Co., Ltd. The main technical indicators are shown in Table 2.

TABLE 2. Parameters of polyacrylamide

\begin{tabular}{cccccc}
\hline \multirow{2}{*}{ Name } & Molecular weight $/ 10^{4}$ & Ionic degree $/ \%$ & PH value & Toxicity & Appearance \\
\hline Polyacrylamide & 1200 & $20-30$ & $5-8$ & Non-toxic & White crystal \\
\hline
\end{tabular}


THE ROLE OF MATERIALS

The polyacrylamide used in this study is an aqueous solution. When it is added to the soil, there is a phenomenon that the degree of agglomeration of similar soil particles is not enough. The adhesion inside the dry soil sample mainly comes from the hydrophobic part of polyacrylamide. The van der Waals force, and the repulsive force between the colloidal particles of the soil plays a leading role when saturated with water (Jung et al. 2017). The effect of polyacrylamide on soil particles is shown in Figure 1.

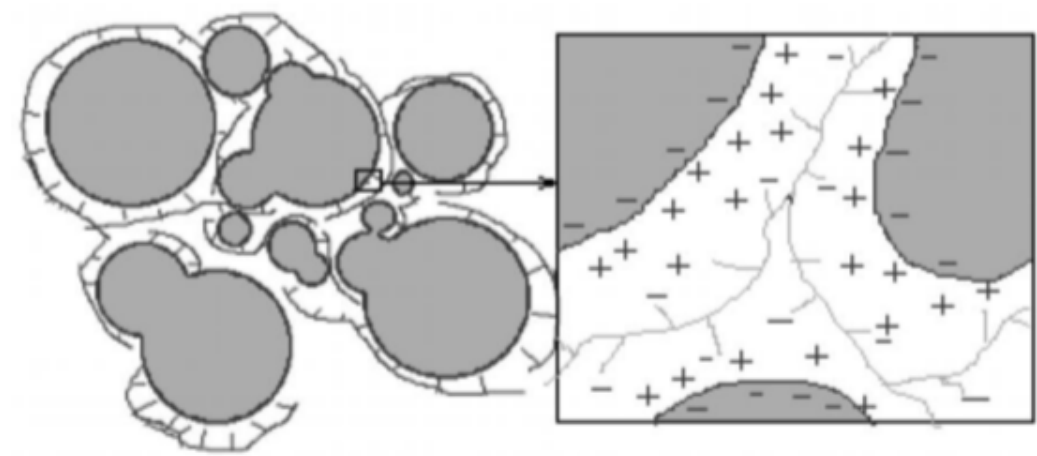

FIGURE 1. PAM and soil reaction

Theoretically, polymer surface-active materials can effectively improve the water stability of the soil, but in actual experiments it was found that this is not the case. The action of the complex system of soil is often disturbed by many factors. In order to improve the stability of the solidified soil, combined with the understanding of the microscopic process of the solidified soil disintegrating with water, it was determined to add lime and PAM combination to enhance the soil agglomeration.

Microscope is the most commonly used technique for evaluating the dispersion state of high molecular polymers. Using the microscope to explore the microscopic mechanism of the material from the perspective of microstructure can solve the difficult and key problems of the Material (Mingjing 2019). In order to characterize the structural change of the reaction between PAM and lime, samples of PAM solution, PAM, and lime solution were prepared and placed in the dark field of the microscope to collect microscopic images. The microscopic images are 100 and 500 times, respectively.
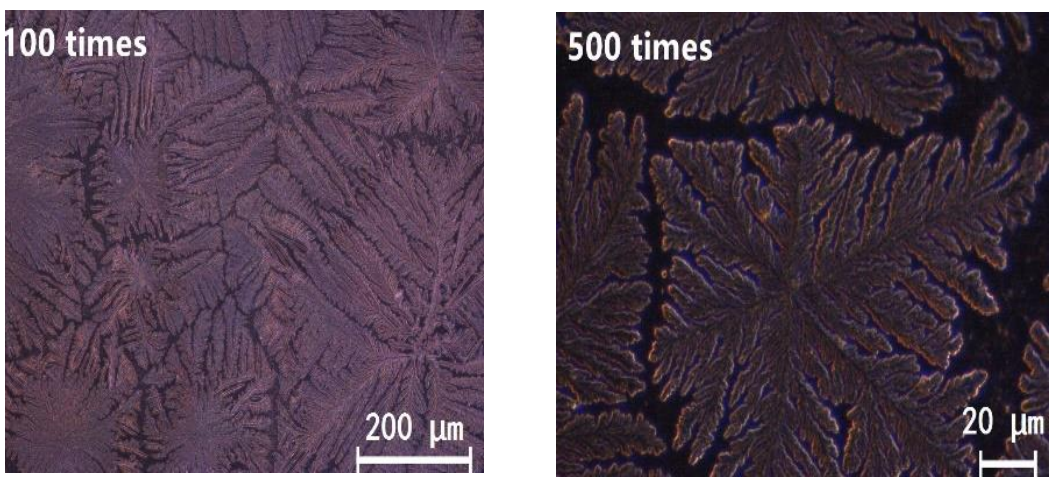

FIGURE 2(a). PAM microscopic images at different multiples 

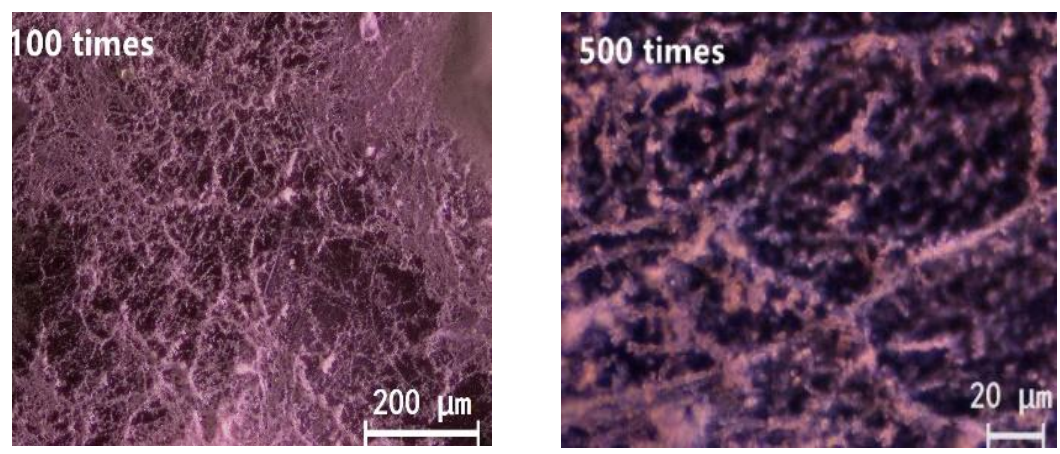

FIGURE 2(b). Microscopic image of PAM reacting with lime at different multiples

As shown in Figure 2(a), it can be clearly seen that the PAM polymer is generally composed of a single polymer. It can be seen that it is closely arranged in a mosaic type when magnified 100 times, and it can be seen that there is a polymer between after magnification 500 times. Gap, there is no connection in the polymer group, distributed as a mosaic phase, the structure of the polymer monomer is a single snowflake structure, and the snowflake structure is composed of many acrylamide single chain connections, making the acrylamide chain in PAM. The amide group at the end is easier to combine with anions to increase its surface activity. It can be seen in the microscopic image in Figure 2(b): after PAM is added to lime, the microstructure is distributed as a spatial network structure after 100 times magnification. At 500 times, it can be seen that the reunion structure is complex, and the spatial network is three-dimensionally distributed. It can be seen from the microscopic image in Figure 2 that there is no connection between the PAM molecular groups. The addition of soil to the soil has little effect on the soil, and the addition of PAM to lime stabilized soil can react with lime to form a larger spatial network structure. It has a wrapping effect, which makes the soil particles reunite structurally enhanced.

\section{EXPERIMENTAL METHODS}

Before the test, the amount of lime and PAM is determined through a large number of tests and previous studies (Jung et al. 2017; Zhang et al. 2013), and then the onedimensional consolidation compression test is carried out by designing the test plan (Table 3 ) by the full factorial method (The proportion of additives are all dry soil mass ratio). Take an air-dried soil sample and measure its moisture content, smash it, pass a $2 \mathrm{~mm}$ sieve for use, weigh a certain amount of PAM and add an appropriate amount of purified water to prepare a PAM solution for use, then add a certain amount of lime to the soil and stir it evenly, add the PAM solution and stir it well, and then place the stew for a whole day and night, prepare samples in three layers according to the compaction test sample preparation method, and demold the prepared samples, take the ring knife coated with petroleum jelly on the inner wall according to JTG E40-2007 'Road Geotechnical Test Regulations', obtain a ring knife sample with a bottom area of $50 \mathrm{~cm}^{2}$ and a height of 2 $\mathrm{cm}$, weigh it and place it on a triple-bar consolidation instrument for 50,100, 200, and $400 \mathrm{kpa}$ consolidation pressure consolidation experiment.

TABLE 3. Dosage of polyacrylamide and lime solidified soil

\begin{tabular}{ccc}
\hline number & PAM $/ \%$ & lime $/ \%$ \\
\hline W0 & 0 & 0 \\
J0 & 0.24 & 0 \\
Js0 & 0 & 8 \\
Js1 & 0.12 & 8
\end{tabular}




\begin{tabular}{lll} 
Js2 & 0.24 & 8 \\
Js3 & 0.36 & 8 \\
Js4 & 0.48 & 8 \\
Js5 & 0.6 & 8 \\
\hline
\end{tabular}

After the consolidation test is completed, the Gemini specific surface area analyzer of American Mac Instruments Co. is used to analyze the pore structure, and the pore distribution is obtained by using the BJH pore distribution calculation model. First take 1-3 g sample in the test tube, put it on the degassing table at $300{ }^{\circ} \mathrm{C}$ for $4 \mathrm{~h}$, after the degassing is completed, remove the sample tube and cool it, weigh the sample weight, Gemini specific surface area analyser performs nitrogen adsorption experiments (Sigmund et al. 2017).

\section{RESULTS AND DISCUSSION}

\section{COMPRESSION CURVE ANALYSIS}

The compressibility of soil refers to the property that the volume of the subgrade becomes smaller under the action of additional load from the outside. The compressibility is mainly caused by the change in the pore structure of the soil, which is related to the composition, type and structure of the soil, and also to the state of stress is closely related, and the compressibility of the solidified soil can directly reflect the solidification effect of the solidified material on the soil (Abhishek 2016). The relationship curve between the porosity ratio e and the consolidation pressure $p$ derived from Terzaghi's one-dimensional consolidation theory is shown in Figure 1, and the test dosage is shown in Table 3.

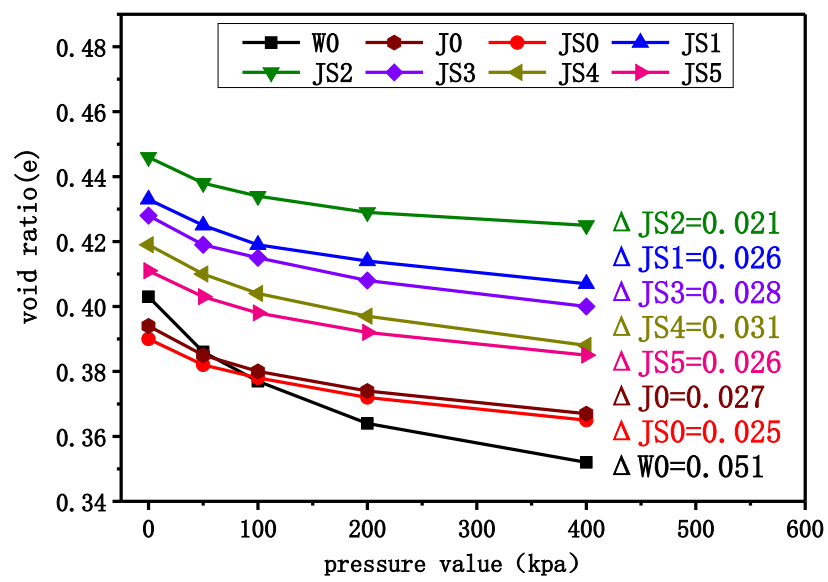

FIGURE 3. Relation curve between void ratio and consolidation pressure

It can be seen from Figure 3 that the porosity ratio decreases with the increase of consolidation pressure. When the lime (or PAM) is added alone, the porosity ratio in the soil decreases and the compression of the soil sample is also reduced, indicating that the lime (PAM).
It has a certain agglomeration effect on the soil particles, which increases the joint filling effect of the soil particles and makes the soil particles denser, resulting in a reduction of the soil compression, indicating that lime has a certain improvement effect on the soil compressibility. 
For the double-mixing experiment, the data shows that the porosity ratio of the solidified soil is increased to some extent, but the compression of the solidified soil is significantly reduced.

The appeal study found that PAM can react with lime to change the internal pore structure of the soil. Leading to a certain increase in the porosity of the solidified soil, but the amount of compression will be greatly reduced. The data shows that when PAM is added to lime stabilized soil, the porosity ratio of the solidified soil is significantly increased and the compression of the solidified soil is significantly reduced. The porosity ratio of the solidified soil increases first and then decreases with the amount of PAM. When the amount reached $0.24 \%$, the porosity ratio was the largest (0.446) and the compression amount was smaller $(\Delta=0.021)$, indicating that the reaction effect with lime was the best when the amount of PAM was $0.24 \%$.

\section{CONSOLIDATION COEFFICIENT ANALYSIS}

The consolidation rate of soil under a certain load can be reflected by the consolidation coefficient. The faster the consolidation rate, the shorter the time for the soil to reach consolidation stability, which is of great significance for the study of soil compressibility (Hsu \& Tsai 2016). The relationship between compression time and compression amount is obtained through indoor consolidation experiments, and then the consolidation coefficient is determined more accurately and conveniently using origin software and the 'square root of time method'.

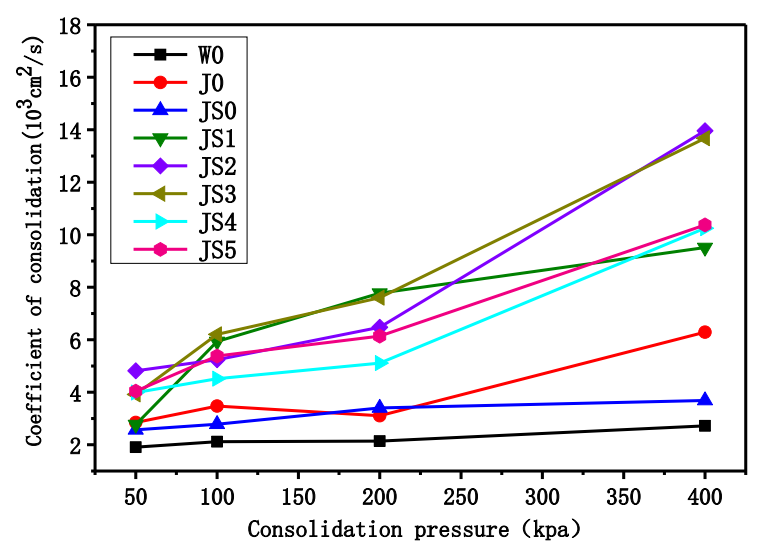

FIGURE 4. Relation curve between coefficient of consolidation and pressure

It can be seen from Figure 4 that the consolidation coefficient of solidified soil increases with the increase of pressure value. Although the backfill soil is only mixed with lime (or PAM), the consolidation coefficient has a certain increase, but the effect is not very good. Obviously, and the relationship between the consolidation coefficient of solidified soil and the amount of lime is weak, indicating that if lime is only added to the soil, the soil particles can be linked together through the hydration reaction of lime, but the effect on the consolidation rate is not. Obviously, it has little effect on the settlement of subgrade after geotechnical engineering; When lime and PAM are added to the soil sample at the same time, it can be seen that the consolidation coefficient of the soil sample has been significantly increased, and the consolidation coefficient has increased significantly with the increase of pressure, indicating that lime and PAM are co-mixed into the soil sample, can greatly accelerate the consolidation rate of solidified soil, therefore, as long as the compaction work meets the requirements during the construction process, the settlement of the subgrade backfill will be basically completed, which has a significant improvement effect on the settlement of the new roadbed after construction. With the increase of PAM content, the consolidation coefficient of solidified soil increases first and then decreases. Among them, the consolidation coefficient of 0.24 and $0.36 \%$ of the solidified soil increases most with the increase of pressure, indicating that there is a threshold value for the amount of the compound, if it is too much, it will inhibit the curing effect of the solidified soil.

\section{PORE STRUCTURE ANALYSIS}

The mesoscopic structural characteristics of the soil are inextricably linked to its engineering characteristics (Wei et al. 2016), therefore, the study of the compressibility of the soil requires the combination of macroscopic characteristics and mesoscopic structure. Through this method, the mechanism of the macroscopic characteristics and the in-depth study of structural changes. 

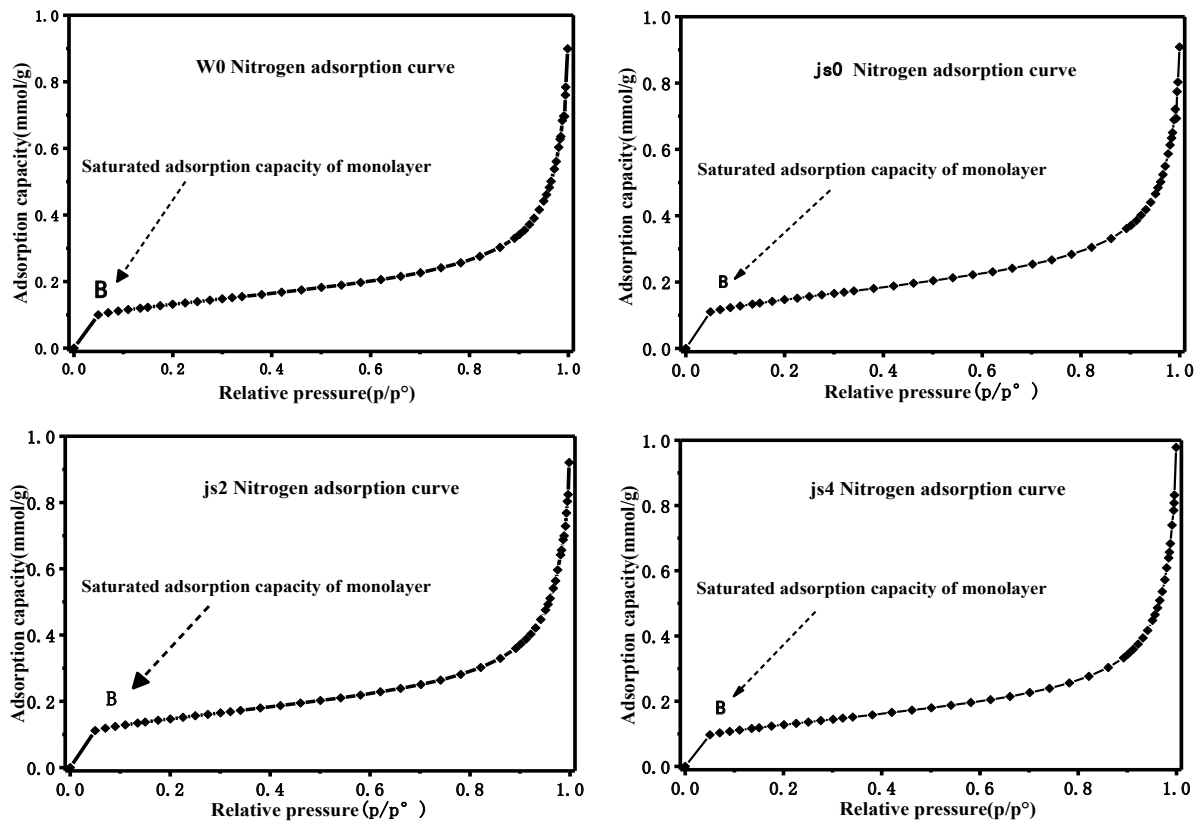

FIGURE 5. Isothermal adsorption curve

The nitrogen adsorption BJH method is developed based on Kelvend's capillary condensation theory. The principle is to assume that the pore volume is a circular tube, and then the nitrogen filled in the measured pore is equivalent to the pore volume. The established capillary condensation calculation model, BJH method is a commonly used model for calculating pore size distribution (Bardestani et al. 2019). The nitrogen isotherm adsorption curve of the soil sample is shown in Figure 5. The figure shows that the adsorption type is type II isotherm. According to the characteristics of the $\mathrm{N}_{2}$ isotherm adsorption curve and the characteristics of the soil sample, select representative samples W0, JS0, JS2, and JS4 (characterization of PAM - The effect of the amount on the pore structure of lime soil). The pore size distribution experiment was carried out, and the percentage of the pore size distribution range in the total pore volume was obtained using BJH method as shown in Figure 6.

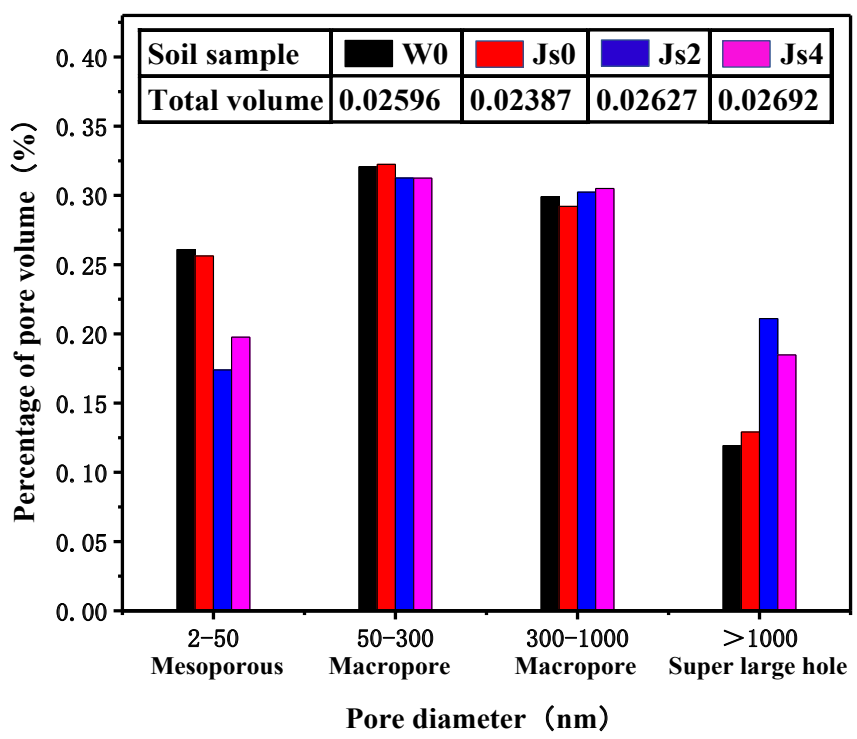

FIGURE 6. Volume percentage of pore diameter 
Figure 6 is the percentage of the total pore volume of the four representative samples with different pore size ranges. It can be seen that the ratio of the pore volume of the control group (W0) and other experimental groups between $50-1000 \mathrm{~nm}$ is not much different from the total volume. The difference is mainly between the super-large pore diameter and the mesopore diameter; The figure shows that the addition of PAM to lime stabilized soil can significantly reduce the mesopore volume (from $26.089 \%$ in the W0 group to $16.769 \%$ in the JS4 group), while the pore volume at more than $1000 \mathrm{~nm}$ increases dramatically (from 1.932 in the W0 group \% increased to $23.477 \%$ of the JS4 group), and there is a trend that the large pore volume has been increasing with the increase of the dosage.

For the soil samples without PAM (W0, JS0), the pore size distribution is not much different, which indicates that the change of lime on the soil sample in the early stage of compression is only the effect of condensation, and it cannot change the internal pore structure of the soil sample. The pore size distribution of post-lime stabilized soil will be similar to that of plain soil, which is also the reason why the compression rate of lime soil and plain soil is small; By comparing and analyzing the pore size distribution percentages of W0, JS2, and JS4, adding PAM to lime stabilized soil can improve the internal pore structure of the soil sample, fill the mesopores in the soil sample, and increase the pore volume of the super-large pores, therefore, the soil the ultra-pore water can be discharged faster through the newly created ultra-large pores in the solidified soil, so that the consolidation rate of the soil body can be increased, the consolidation settlement can be completed faster, and the appeal of the macroscopic characteristics is consistent.

\section{LOGARITHMIC INTEGRAL PORE VOLUME ANALYSIS}

There are several types of pore size distribution maps that can be drawn using the BJH method: A. cumulative pore volume (cumulative specific pore volume)/pore diameter diagram; B. differential pore volume (differential pore volume, $\mathrm{dV} / \mathrm{dW}$ )/pore diameter diagram; C. log differential pore volume $(\mathrm{dV} / \mathrm{d} \log \mathrm{W}) /$ Aperture chart. In this study, logarithmic integral pore volume was used according to the pore size distribution of soil samples (Figure 7).

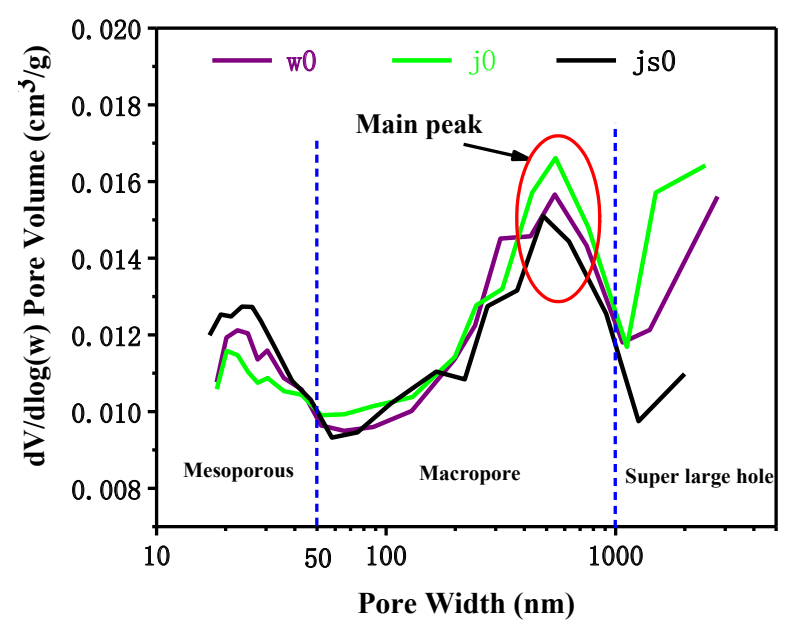

(a)

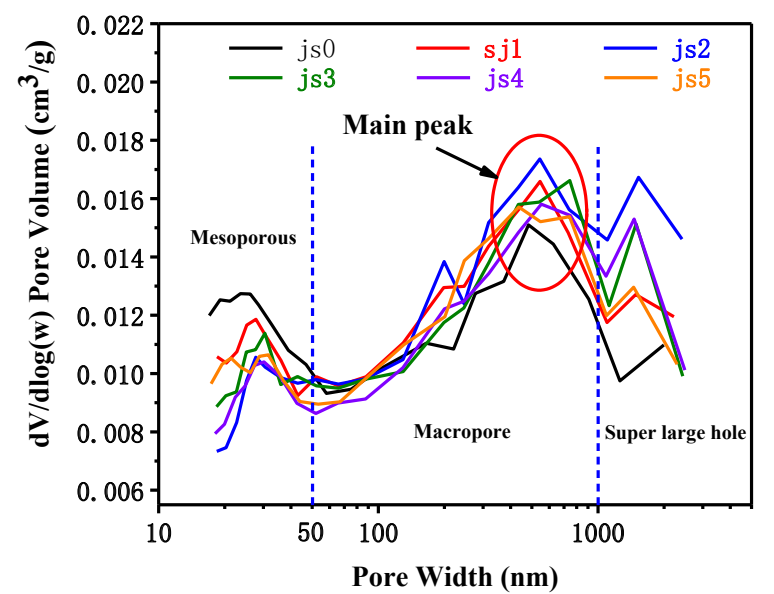

(b)

FIGURE 7. . Log integral pore volume (a) The pore volume of lime and PAM added to the soil, and (b) Pore volume of lime stabilized soil with different PAM 
The pore volume distribution of different solidified soils is characterized by the pore volume distribution characteristics of different pore sizes (Figure 7). The pore size distribution curve is roughly divided into two types: double peak type (W0, J0, JS 0) and triple peak type (JS1, JS2, JS3, JS4, JS5). There is a main peak in the double peak type curve (pore size is between 300-1000 $\mathrm{nm}$ ) and a secondary peak (pore diameter between 10-50 $\mathrm{nm}$ ), the trimodal curve mainly has a major peak (pore diameter between $300-800 \mathrm{~nm}$ ) and two secondary peaks (pore diameter between 10-50 and 1000-2000 nm). Both curves have larger pore volume and the three-peak curve is mainly improved in the range of super- large pore volume. Comparing Figure 7(a), when lime is added to plain soil, the mesopore volume will increase and there will be a small decrease in the range of large pore volume. It can be seen that the hydration reaction of lime in the soil can make smaller mesopores increase, and agglomeration will reduce the accumulation of large pore volume. When PAM is added to plain soil, the network structure of PAM itself will cause the super macropores to agglomerate and increase the macropore volume.

Figure 7(b) is the change of pore structure of lime stabilized soil with different dosages of PAM. It can be seen from the figure that when PAM is added into lime stabilized soil, it will reduce the mesopore volume and change the macropore volume to large, at the same time, it will also produce super-large pores that were not available before; It indicates that the reaction between PAM and lime will cause the accumulation of large soil particles and increase the number of large pores, and there will be new super large pores between adjacent aggregates.

When the soil body is subjected to external loads, the pore water in the soil and the pore structure of the soil will change, which will deform the soil body. Deformation can occur more easily and the settlement of solidified soil can be completed as soon as possible, and the mesopores in the soil are filled, which will make the soil denser, which result in the reduction of compression of the solidified soil. Comparing the appeal analysis, it can be seen that PAM can improve the pore structure of lime stabilized soil, reduce the mesopore volume of the soil sample and increase the large pore volume, which will have a huge improvement in the soil compression amount and compression rate.

\section{CONCLUSION}

In this paper, different levels of polyacrylamide were mixed into the lime-stabilized soil. From the perspective of the combination of macro-micro, the following conclusions were drawn: Adding lime to the soil can improve the compression of the soil to a certain extent, but it has little effect on the pore ratio of the soil; mixing lime and polyacrylamide in the soil, the reaction between lime and polyacrylamide. The product can reduce the compression of the soil, and at the same time can increase the porosity of the solidified soil. Lime mixed with polyacrylamide and mixed into the soil can greatly increase the consolidation rate of the soil, and the time for consolidation and stability of the soil is greatly shortened, reducing the amount of post-construction settlement and compressibility of the soil greater impact. Lime has little effect on the internal pore structure of the soil, and can only play the role of condensed soil particles; polyacrylamide incorporated into lime stabilized soil can improve the internal pore structure of the soil sample, reduce the pore volume of mesopores, and increase the oversize. The pore volume leads to an increase in the consolidation rate of the solidified soil, which shortens the time for the soil to reach consolidation stability, which is consistent with the analysis of the macroscopic characteristics.

\section{ACKNOWLEDGEMENTS}

Thanks to the scholars for their research, the article has sufficient theoretical basis. Thank you for the scientific research funding project of Hongrui Road and Bridge Engineering Technology Research Institute in Inner Mongolia. At the same time, I thank the teachers and scientific research team for their support and help in the process of writing the article.

\section{REFERENCES}

Abhishek, S.V., Rajyalakshmi, K. \& Madhav, M.R. 2016. Engineering of ground with granular piles: A critical review. International Journal of Geotechnical Engineering 10(4): 337-357.

Bardestani, R., Patience, G.S. \& Kaliaguine, S. 2019. Experimental methods in chemical engineering: Specific surface area and pore size distribution measurementsBET, BJH, and DFT. The Canadian Journal of Chemical Engineering 97(11): 2781-2791.

Barvenik, F.W. 1994. Polyacrylamide characteristics related to soil applications. Soil Science Society of America Journal 158(4): 235-243.

Fan, J.H. 2008. Multi-scale analysis of material deformation and failure. Science Press 2008(1).

Gadouri, H., Harichane, K. \& Ghrici, M. 2017. Effect of sodium sulphate on the shear strength of clayey soils stabilised with additives. Arabian Journal of Geosciences 10(218): 1-10.

Georgees, R.N., Hassan, R.A., Evans, R.P. \& Jegatheesan, P. 2018. Resilient response characterization of pavement foundation materials using a polyacrylamide-based stabilizer. Journal of Materials in Civil Engineering 30(1): 04017252.

Hsu, T.W. \& Tsai, T.H. 2016. Combined vertical and radial consolidation under time- dependent loading. International Journal of Geomechanics 16(3): 04015073.

James, J. \& Pandian, P.K. 2018. Bagasse ash as an auxiliary additive to lime stabilization of an expansive soil: Strength and microstructural investigation. Advances in Civil Engineering 2018: 1-16.

Jha, A.K. \& Sivapullaiah, P.V. 2017. Physical and strength development in lime treated gypseous soil with fly ash micro-analyses. Applied Clay Science 145: 17-27. 
Jung, J., Ku, T. \& Ahn, J. 2017. Small strain stiffness of unsaturated sands containing a polyacrylamide solution. Materials (Basel) 10(4): 401.

Keramatikerman, M., Chegenizadeh, A. \& Nikraz, H. 2016. Effect of GGBFS and lime binders on the engineering properties of clay. Applied Clay Science 132(2016): 722-730.

Keykha, H.A., Mohamadzadeh, H., Asadi, A. \& Kawasaki, S. 2019. Ammonium-free carbonate-producing bacteria as an ecofriendly soil biostabilizer. Geotechnical Testing Journal 42(1): 19-29.

Lentz, R.D. 2015. Polyacrylamide and biopolymer effects on flocculation, aggregate stability, and water seepage in a silt loam. Geoderma 241: 289-294.

Li, Y.C., Min, X.B., Chai, L.Y., Shi, M.Q., Tang, C.J., Wang, Q.W. \& Liyang, W.J. 2016. Co-treatment of gypsum sludge and $\mathrm{Pb} /$ $\mathrm{Zn}$ smelting slag for the solidification of sludge containing arsenic and heavy metals. Journal of Environmental Management 181: 756-761.

Mamedov, A.I., Wagner, L.E., Huang, C., Norton, L.D. \& Levy, G.J. 2010. Polyacrylamide effects on aggregate and structure stability of soils with different clay mineralogy. Soil Science Society of America Journal 74(5): 1720-1732.

Mashifana, T.P., Okonta, F.N. \& Ntuli, F. 2018. Geotechnical properties and microstructure of lime-fly ash-phosphogypsumstabilized soil. Advances in Civil Engineering 2018: 1-9.

Mingjing, J. 2019. New horizons of modern soil mechanics research-macro and micro soil mechanics. Chinese Journal of Geotechnical Engineering 42(2): 195-254.

Mohammadi, A., Dehestani, M. \& Shooshpasha, I. 2015. Mechanical properties of sandy soil stabilized with modified sulfur. Journal of Materials in Civil Engineering 27(4): 04014140.

Naeini, S.A., Naderinia, B. \& Izadi, E. 2012. Unconfined compressive strength of clayey soils stabilized with waterborne polymer. KSCE Journal of Civil Engineering 16(6): 943-949.

Nilo, C.C.P.D., Rodrigo, B.S.P.D. \& Hugo, C.S.F.M.S. 2019. Short- and long-term effects of sodium chloride on strength and durability of coal fly ash stabilized with carbide lime. Canadian Geotechnical Journal 56(12): 1929-1939.

Ojuri, O.O., Adavi, A.A. \& Oluwatuyi, O.E. 2017. Geotechnical and environmental evaluation of lime-cement stabilized soil-mine tailing mixtures for highway construction. Transportation Geotechnics 10: 1-12.
Sharma, L.K., Sirdesai, N.N., Sharma, K.M. \& Singh, T.N. 2018 Experimental study to examine the independent roles of lime and cement on the stabilization of a mountain soil: A comparative study. Applied Clay Science 152(2018): 183-195.

Sigmund, G., Huffer, T., Hofmann, T. \& Kah, M. 2017. Biochar total surface area and total pore volume determined by $\mathrm{N}_{2}$ and $\mathrm{CO}_{2}$ physisorption are strongly influenced by degassing temperature. Science of The Total Environment 580(2018): 770-775.

Soltani-Jigheh, H., Bagheri, M. \& Amani-Ghadim, A.R. 2019. Use of hydrophilic polymeric stabilizer to improve strength and durability of fine-grained soils. Cold Regions Science and Technology 157: 187-195.

Wang, Y., Li, S. \& Yang, H. 2018. In situ stabilization of some mercury-containing soils using organically modified montmorillonite loading by thiol-based material. Journal of Soils and Sediments 19(4): 1767-1774

Wei, X., Duc, M., Hattab, M., Reuschlé, T., Taibi, S. \& Fleureau, J.M. 2016. Effect of decompression and suction on macroscopic and microscopic behavior of a clay rock. Acta Geotechnica 12(1): 47-65.

Zhang, M., Guo, H., El-Korchi, T., Zhang, G. \& Tao, M. 2013. Experimental feasibility study of geopolymer as the next-generation soil stabilizer. Construction and Building Materials 47(22): 1468-1478.

Mingxing Gao*, Feilong Yuan \& Yanhua Xue

College of Energy and Transportation Engineering

Inner Mongolia

Agricultural University

Hohhot, Inner Mongolia, 010018

China

Peng Guan

Hongrui Road and Bridge Engineering Science

Technology Research Institute

Hinggan League, Inner Mongolia, 137400

China

*Corresponding author; email: gaomingxing_2000@imau.edu.cn

Received: 17 December 2019

Accepted: 21 April 2020 